\title{
Formalisasi Beragama Penganut Marapu Melalui Pendidikan Formal Pada Masyarakat Kampung Tarung di Sumba Barat, NTT
}

\author{
Ida Bagus Oka Wedasantara*, I Nyoman Suarsana \\ Prodi Antropologi Fakultas Ilmu Budaya Unud \\ [wedaoka@yahoo.co.id] \\ *Corresponding Author
}

\begin{abstract}
The classification between religion and believer by the apparatus of the Indonesia state and zendeling/missionaries creates persuasive discrimination to Marapu believer in Tarung Village. Formal education was made religious formalization instrument to Marapu believer because in the practice, students must profess which is recognized juridically by the apparatus of the Indonesian state. Formulation of the problem in this research involve (1) how the process of religious formalization to Marapu believer through formal education? and (2) how implication of religious formalization to Marapu religiousity in Tarung Village?. The formalization Marapu religious through formal education to Tarung's people can be studied by applying the theory of hegemony, religious conversion theory, and theological inculturation theory. While the concepts used as a reference in this research are religious formalization, Marapu, formal education, and implication. This qualitative research uses etnography research methods including the technique of collecting data through the observation, interview, literatur study and data analysis in order to process data findings. The research findings show that Marapu believer must be Christianity or Catholic in order to get formal education. Marapu as teachings without scripture, make a different interpretation in Tarung's people, it can be an obstacle for reach of common identity. For Tarung's people "half Marapu and half Christian/Catholic" is two principle that workable, behind the succumb strategy between Marapu leaders and Christian/Catholic leaders for the sake of certain interests. Marapu of Tarung's people have inculturation with basic Christianity/Catholicism.
\end{abstract} Keywords: $\begin{aligned} & \text { Religious Formalization, Marapu, Formal Education, } \\ & \text { Implication }\end{aligned}$

\begin{abstract}
Abstrak
Klasifikasi antara agama dan aliran kepercayaan oleh pemerintah negara Indonesia serta zendeling/misionaris menghasilkan diskriminasi persuasif terhadap penganut Marapu di Kampung Tarung. Pendidikan formal dijadikan alat formalisasi beragama terhadap penganut Marapu karena dalam praktiknya, peserta didik tersebut diharuskan menganut agama yang diakui secara yuridis oleh pemerintah negara Indonesia. Rumusan masalah
\end{abstract}


dalam penelitian ini meliputi (1) bagaimana proses formalisasi beragama pada penganut Marapu melalui pendidikan formal? dan (2) bagaimana implikasi formalisasi beragama tersebut terhadap keagamaan Marapu di Kampung Tarung?. Formalisasi beragama penganut Marapu melalui pendidikan formal pada masyarakat Kampung Tarung dapat dikaji dengan mengaplikasikan teori hegemoni, teori konversi agama, dan teori inkulturasi teologis. Sedangkan konsep yang digunakan sebagai acuan dalam penelitian ini, yaitu formalisasi beragama, Marapu, pendidikan formal, dan implikasi. Penelitian kualitatif dilakukan dan diperoleh dengan model penelitian etnografi, meliputi teknik pengumpulan data melalui observasi, wawancara, studi pustaka, serta analisis data guna mengolah temuan lapangan. Hasil penelitian memperlihatkan penganut Marapu harus menganut Kristen atau Katolik agar dapat mengenyam pendidikan formal. Marapu sebagai ajaran tanpa kitab suci tertulis, menciptakan penafsiran berbeda-beda dalam masyarakat Kampung Tarung secara berkesinambungan, hal itu menjadi penghalang untuk mencapai identitas bersama. Bagi masyarakat Kampung Tarung menganut "setengah Marapu dan setengah Kristen/Katolik" adalah dua prinsip yang bisa diterapkan, dibalik strategi mengalah antara tokoh Marapu dan Kristen/Katolik demi kepentingan tertentu. Ke-Marapu-an masyarakat Kampung Tarung telah mengalami inkulturasi dengan dasar ajaran agama Kristen/Katolik.

Kata kunci: Formalisasi Beragama, Marapu, Pendidikan Formal, Implikasi

\section{Latar Belakang}

Masyarakat Indonesia merupakan penganut agama yang beragam, penjelasan Penpres No. 1/PNPS/1965 menyebutkan bahwa terdapat enam agama yang dianut oleh penduduk Indonesia, yaitu Islam, Kristen, Katolik, Hindu, Budha, dan Khong $\mathrm{Cu}$. Sedangkan agama-agama yang belum mendapatkan pengakuan secara yuridis oleh pemerintah negara Indonesia, sampai saat ini digolongkan sebagai aliran kepercayaan.

Belakangan ini, publik dikejutkan oleh putusan hakim MK RI yang mengabulkan pencantuman "Penghayat Kepercayaan" pada kolom agama Kartu Keluarga dan Kartu Tanda Penduduk (Putusan MK RI Nomor 97/PUUXIV/2016 Demi Keadilan Berdasarkan Ketuhanan Yang Maha Esa). Pasca putusan tersebut dibacakan tanggal 7 November 2017, merupakan kabar menggembirakan khususnya bagi panganut di luar enam agama karena mereka tidak perlu lagi memalsukan maupun mengosongkan identitas agamanya, meskipun tidak dapat menunjukkan identitas agamanya secara spesifik, mengingat ada banyaknya aliran kepercayaan di Indonesia. Kebijakan generalisasi keagamaan itu meninggalkan suatu esensi kritis bahwa mereka masihlah "aliran kepercayaan" dan bukanlah "agama".

Marapu adalah salah satu dari banyaknya aliran kepercayaan yang dikabulkan permohonannya oleh hakim MK RI. Penganut Marapu dapat dijumpai di Pulau Sumba, Nusa Tenggara Timur. Mereka yang menganut ajaran nenek moyangnya itu tetap menjalankan ritual-ritual Marapu, seperti ritual menyangkut siklus kehidupan manusia dan ritual besarnya, yakni Wulla Poddu pada masyarakat Kampung Tarung di Kabupaten Sumba Barat. Masyarakat Kampung Tarung masih pula mempertahankan rumah tradisionalnya. Di tengah pemukiman mereka terdapat 
banyak batu kubur sebagai tempat jenazah nenek moyang mereka bersemayam. Mereka percaya jika rumah tradisional, batu kubur, dan seluruh ritual yang dilakukan berkaitan erat dengan ajaran yang diwarisankan oleh nenek moyangnya.

Kampung Tarung merupakan salah satu kampung yang terletak di puncak bukit Pulau Sumba, berada di wilayah adminsitratif Kelurahan Sobawawi RW 9 RT 20, Kecamatan Loli, Kabupaten Sumba Barat, NTT. Sebagian masyarakat Kampung Tarung adalah penganut Marapu dan sebagiannya lagi menganut Katolik serta Kristen. Berdasarkan data penduduk Kelurahan Sobawawi, tercatat penduduk Kampung Tarung berjumlah 210 jiwa, dengan pembagian penganut Katolik berjumlah 81 jiwa (38,58\%), aliran kepercayaan (Marapu) berjumlah 73 jiwa (34,76\%), dan 56 jiwa $(26,66 \%)$ yakni penganut Kristen (dalam angka tahun 2014). Penganut Marapu terdiri dari para orang tua dan anak-anak yang tidak/telah selesai mengenyam pendidikan formal, sedangkan sebagian besar penganut Katolik dan Kristen merupakan anak-anak yang masih mengenyam pendidikan formal. Data penduduk tersebut juga memperlihatkan jika ada dua sampai tiga agama yang berbeda dalam satu keluarga inti di Kampung Tarung.

Bagi masyarakat Kampung Tarung, wajar adanya hal semacam di atas. Karena realitasnya dalam praktik pendidikan formal terutama di Sumba Barat, peserta didik dari Kampung Tarung wajib menganut salah satu agama yang diakui secara yuridis oleh pemerintah negara Indonesia, yaitu Kristen atau Katolik. Saat pendaftaran masuk pendidikan formal, pencantuman identitas agama itu diperlukan agar peserta didik mendapatkan mata pelajaran pendidikan agama. Pihak pendidik tentu memiliki argumen mendasar atas praktik tersebut, yakni berpedoman pada UU RI No. 20 Tahun 2003 tentang Sisdiknas, Pasal 12 ayat (1A).

Penganut Marapu memang sudah terbebas dari diskriminasi administrasi kependudukan, tetapi implementasi keputusan Mahkamah Konstitusi RI belum menyentuh penyelesaian diskriminasi keagamaan dalam praktik pendidikan formal di Sumba Barat. Bahkan penindasan itu telah terkonstruksi semenjak zendeling dan misionaris melakukan kristenisasi/katolikisasi di Tanah Marapu pada masa Indonesia di bawah kolonial Belanda, terbukti dari banyaknya masyarakat Sumba Barat khususnya di Kampung Tarung yang kini menganut Kristen dan Katolik.

Berbagai kebijakan pemerintah negara Indonesia telah mempersulit penganut Marapu memperoleh pendidikan formal karena tergolong aliran kepercayaan. Upaya yang dilakukan penganut Marapu di Kampung Tarung adalah dengan menganut Kristen atau Katolik. Sehingga terjadi fenomena formalisasi beragama pada penganut Marapu di Kampung Tarung.

\section{Pokok Permasalahan}

Berdasarkan pada latar belakang di atas, maka permasalahan dapat dirumuskan sebagai berikut:

a. Bagaimana proses formalisasi beragama pada penganut Marapu melalui pendidikan formal?

b. Bagaimana implikasi formalisasi beragama tersebut terhadap keagamaan Marapu di Kampung Tarung?

\section{Tujuan Penelitian}

Adapun tujuan dari penelitian ini, sebagai berikut: 1) Untuk mengetahui proses formalisasi beragama pada penganut Marapu melalui pendidikan formal. 2) Untuk mengungkap implikasi 
formalisasi beragama tersebut terhadap keagamaan Marapu di Kampung Tarung.

\section{Metode Penelitian}

Penelitian menggunakan metode kualitatif yang dilakukan dengan model penelitian etnografi. Penelitian berlokasi di Kampung Tarung, Kelurahan Sobawawi, Kecamatan Loli, Kabupaten Sumba Barat, NTT. Pemilihan lokasi didasari pada pertimbangan bahwa sebagian masyarakatnya merupakan penganut Marapu yang mewakili budaya Loli, terutama sebagai pusat penyelenggara ritual Wulla Poddu, dan letaknya berada di tengah kota Waikabubak sebagai pusat modernisasi suatu daerah, walau demikian masyarakat Kampung Tarung teguh menjaga ajaran leluhurnya. Guna melengkapi data penelitian dilakukan juga di beberapa sekolah, gereja, dan kantor kelurahan Sumba Barat.

Jenis data dalam penelitian ini meliputi data kualitatif yang deskriptif serta data kuantitatif berupa angka sebagai pelengkap, bersumber dari data primer melalui observasi dan wawancara serta data sekunder yang menunjang hasil penelitian didapat melalui studi pustaka. Penentuan informan dilakukan dengan teknik purposive sampling, informan kunci ialah Rato Rumata selaku imam Marapu / ketua adat dari seluruh Kabisu di Kampung Tarung, total informan berjumlah 14 orang dari kalangan peserta didik; pendidik; pendeta; pengurus gereja; ketua RT; dan masyarakat Kampung Tarung.

\section{Hasil dan Pembahasan}

\subsection{Proses Formalisasi Beragama Penganut Marapu Melalui Pendidikan Formal}

Keagamaan Marapu kini semakin terdesak, kepunahan bisa saja terjadi bila penolakan datang terus menerus, terutama di dunia pendidikan formal.
Formalisasi beragama diartikan sebagai suatu proses penyesuaian beragama berdasarkan pada peraturan yang sah. Pernyataan ini dapat dilihat pada berbagai kebijakan pemerintah negara Indonesia, salah satunya yakni pemberlakuan Penetapan Presiden No. 1/PNPS/1965 yang mengakui adanya enam agama. Marapu sebagai suatu pedoman beragama sebagian besar masyarakat Kampung Tarung, terformalisasi dari pemberlakuan peraturan tersebut yang telah diangkat menjadi Undang-Undang oleh Soeharto pada zamannya.

UU mengenai pengakuan agama dan penggolongan aliran kepercayaan tersebut sampai saat ini masih berlaku dan bahkan mempengaruhi UU RI No. 20 Tahun 2003 tentang Sistem Pendidikan Nasional, Pasal 12 ayat (1A) "Setiap peserta didik pada setiap satuan pendidikan berhak mendapatkan pendidikan agama sesuai dengan agama yang dianutnya dan diajarkan oleh pendidik yang seagama" dan Pasal 37 ayat (1A) "Kurikulum pendidikan dasar dan menengah wajib memuat pendidikan agama".

Pekabaran Injil di Sumba sejak tahun 1881 hingga kini, turut andil dalam fenomena formalisasi beragama penganut Marapu. Bagaimana pun, para zendeling dan misionarislah yang pertama mengenalkan pendidikan formal kepada masyarakat Sumba Barat, dimana pada saat itu seluruh penduduk disana masih menganut Marapu. Kini, lembaga pendidikan formal milik yayasan agama (swasta) tetap tidak kalah eksis dibanding milik pemerintah negara Indonesia (negeri), terbukti dari masih berdirinya Yapmas (Yayasan Persekolahan Masehi di Sumba) milik GKS (Gereja Kristen Sumba) dan Yapnusda (Yayasan Persekolahan Nusa Cendana) milik Gereja Katolik di Sumba/NTT. 
Para peserta didik (penganut Marapu) dari Kampung Tarung yang mengikuti mata pelajaran pendidikan agama Kristen/Katolik tidak akan langsung disahkan melalui baptisan. Ia akan didoktrin terlebih dahulu ajaranajaran Alkitab/Injil di lembaga pendidikan formal baik swasta maupun negeri. Kapita (2008: 26-27) mengungkapkan secara terang-terangan bahwa "bibit Injil dapat ditabur dalam batin anak-anak, berapa banyak orang Sumba yang masuk Kristen sekarang adalah karena hasil bibit Injil yang ditabur pada sekolah-sekolah". Mereka juga tidak diperbolehkan membawabawa kepercayaannya ke sekolah dan mengikuti tata cara Kristen/Katolik, terutama wajib bagi yang bersekolah di yayasan agama.

Doktrin pendidikan formal berlanjut pada sebuah peraturan sekolah di Sumba Barat, dimana semua peserta didik wajib mengikuti sekolah minggu. Pada sekolah minggu, anak-anak itu diajarkan menari/drama untuk pementasan gereja, menyanyi lagu rohani, menceritakan/mendengar kisah para Rasul, dan mendengarkan khotbah. Buku sekolah minggu yang ditanda tangan oleh pendeta Kristen/Katolik menjadi bukti bahwa mereka betul telah datang ke gereja. Lancarnya proses ajar mengajar mata pelajaran pendidikan agama, karena peserta didik bisa menerima pembelajaran tersebut, walapun ada beberapa pesera didik yang masih menjalankan ritual-ritual Marapu.

Pada umumnya, sekolah-sekolah di Indonesia membudayakan seluruh peserta didiknya untuk berdoa saat akan mengawali pelajaran pertama dan beranjak pulang sekolah. Demikian pula di Sumba Barat, dimana ibadah di sekolah diikuti pula oleh para peserta didik (penganut Marapu) dan tidak ada penolakan dari orang tua jika anaknya diagamakan.
Para peserta didik dari Kampung Tarung harus menyembunyikan identitas Marapunya pada kolom agama KK dan dalam data lembaga pendidikan formal, menerima ajaran Kristen/Katolik yang bertentangan dengan ajaran Marapu, mematuhi tata cara Kristen/Katolik di sekolah, mengikuti sidi serta menerima untuk dibaptis, dan ada pula beberapa orang yang sampai menanggalkan keMarapu-annya. Semua itu guna memperoleh hak pendidikan formal, strategi yang dilakukan penganut Marapu di Kampung Tarung hanya mengalah agar dapat bertahan.

\subsection{Implikasi Formalisasi Beragama \\ Terhadap Keagamaan Marapu}

Marapu sebagai keagamaan leluhur masyarakat Sumba, merupakan ajaran tanpa kitab suci tertulis. Penganutnya percaya, jika itu menandakan bahwa ajaran Marapu telah ada sejak manusia belum mengenal tulisan yang kini manusia pergunakan. Segala keagamaan Marapu dilakukan berdasarkan pengalaman-pengalaman yang diterima dari ajaran para pendahulu. Begitu pula, sebagaimana orang-orang dari pengalamannya dapat menafsirkan Marapu.

Beberapa penulis berusaha memberi penafsiran tentang Marapu berdasarkan penguraian kata "Marapu", namun diragukan kebenarannya oleh Rato Rumata Kampung Tarung. Sebab, suatu kalimat syair sakral menyebutkan Dappatekkitamo Dappanungara "tidak disebut gelar tidak disebut nama / tidak disebutkan namaNya dengan sembarangan" artinya bahwa namaNya pemali untuk dipikirkan maupun diucapkan oleh ciptaannya. Karena, Pamomowiwi Pamakkemata "tidak ada yang menyamai Tuhan" artinya seluruh ciptaanNya tidak dapat menyamai kuasaNya, apalagi menafsirkanNya. Penganut Marapu Kampung Tarung menyebut nama Tuhan dengan ciri 
kuasaNya yakni Ama Ama Wolu - Inna Ama Rawi adalah "Yang menciptakan langit dan bumi/Tuhan Yang Maha Kuasa". Bagi Rato Rumata, Marapu memiliki kepercayaan yang sama seperti enam agama yang diakui secara yuridis oleh pemerintah negara Indonesia. Kepercayaan Marapu bertujuan kepada Tuhan, tidak hanya sekedar penyembahan kepada nenek moyang. Leluhur dipandang sebagai perantara antara manusia dengan Pencipta.

Indonesia sebagai bangsa beragama, sampai saat ini tetap konsisten memandang Marapu adalah aliran kepercayaan, bukan suatu agama. Penggolongan ini menjelaskan kepada warga negara bahwa aliran kepercayaan memiliki posisi di bawah agama. Sehingga dalam praktik pendidikan formal, peserta didik penganut Marapu tidak memiliki pilihan selain mengganti identitas agamanya ke salah satu agama yang diakui secara yuridis oleh pemerintah negara Indonesia. Namun belakangkan ini, beberapa masyarakat Indonesia sependapat dengan tulisan karya Subagya (1981), bahwa di luar enam agama yang diakui secara yuridis oleh pemerintah Indonesia merupakan "Agama Asli Indonesia".

Ucapan merendahkan oleh masyarakat non-Marapu Sumba bahwa ajaran Marapu adalah kafir, sesat maupun berhala tidak pernah penulis temukan selama melakukan penelitian lapangan. Meskipun beberapa diantaranya masih memiliki tafsir demikian dengan redaksional yang berbeda, seperti orang kampung/tradisional; aliran kepercayaan; bukan agama; adat/budaya; warisan nenek moyang; pemikiran kuno; ajaran lisan; dan miring, digunakan oleh penganut non-Marapu atau khususnya Kristen/Katolik sebagai langkah kehatihatian atau kewaspadaan terhadap konflik sosial-budaya masyarakat dan hukum perundang-undangan yang berlaku di Indonesia.

Seluruh penafsiran mengenai Marapu yang dipaparkan di atas membawa kita pada apa yang disebut oleh Thomas Kuhn (dalam Tilaar, 2009: 148) bahwa tidak ada kebenaran yang mutlak dan abadi karena semuanya tergantung pada perspektif yang digunakan. Kebenaran atas tafsir-tafsir Marapu itu, berimplikasi terhadap masyarakat Kampung Tarung, terutama penganut Marapu mengenai bagaimana ia menentukan tafsir yang akan menjadi ideologinya tentang ke-Marapu-an. Hal tersebut menciptakan penafsiran yang berbeda-beda dalam masyarakat Kampung Tarung secara berkesinambungan, dan oleh karena itu akan sulit bagi mereka untuk menghasilkan suatu kesepakatan identitas bersama.

Realitas kehidupan yang dijalani penganut Marapu Kampung Tarung untuk memenuhi hak pendidikan formal, mengharuskan mereka menganut agama yang diakui secara yuridis oleh pemerintah negara Indonesia. Tidak ada penolakan dalam diri mereka atas prinsip baru itu dan tidak mudah bagi mereka untuk menanggalkan prinsip sebelumnya, dua prinsip tersebut diterima sebagaimana mestinya. Sehingga apa yang dialami masyarakat Kampung Tarung dari formalisasi beragama tersebut merupakan dualisme beragama atau masyarakat setempat menyebut hal itu dengan kalimat "setengah Marapu dan setengah Kristen/Katolik".

Kedua prinsip itu saling berlawanan, tetapi kesatuan seimbang yang saling berdampingan dalam iman manusia itu. Perilaku dualisme beragama dapat dijumpai pada kalangan masyarakat Kampung Tarung terutama yang sedang/telah mengenyam pendidikan formal. 
Perilaku mendua masyarakat Kampung Tarung dapat dilihat dalam kehidupan beragamanya. Mereka tetap melaksanakan ritual-ritual Marapu, terutama keterlibatannya saat Wulla Poddu. Masyarakat ini pun di sisi lain juga berdoa kepada Yesus Kristus dan/atau Bunda Maria di lembaga pendidikan formal, saat mengikuti sekolah minggu, dan tidak jarang beberapa orang pun rajin mengikuti kebaktian di gereja. Keadaan itu menghasilkan antara tokoh Marapu dan tokoh Kristen/Katolik saling mengalah, dengan melonggarkan batasan-batasan ajaran-Nya. Namun di balik keadaan tersebut, kedua belah pihak mengusahakan kepentingannya tersendiri. Dimana, pihak Marapu berusaha diakui sebagai agama secara yuridis oleh pemerintah negara Indonesia, sedangkan pihak Kristen/Katolik mengusahakan inkulturasi terhadap ke-Marapu-an.

Pada konteks kehidupan penganut Marapu Kampung Tarung, dasar ajaran Marapu telah mengalami inkulturasi dengan dasar ajaran Kristen atau Katolik, yakni Injil. Penyesuaian itu melalui rekayasa atas keterlibatan pihak penguasa menggunakan lembaga pendidikan formal yang menjadikan hasil perekayasaan tersebut berimplikasi terhadap ke-Marapu-an Kampung Tarung, antara lain:

a. Penyebutan Tuhan dengan mengucapkan ciri kuasaNya Ama Ama Wolu - Inna Ama Rawi, mengandung arti bahwa ialah yang menciptakan langit dan bumi atau Tuhan Yang Maha Kuasa. Sebutan ini terdapat dalam Alkitab Kejadian 1: 1 "Pada mulanya Allah menciptakan langit dan bumi". Bagi masyarakat Sumba Barat, panggilan Ama adalah sebutan untuk laki-laki dan Inna sebutan untuk perempuan, sebuatan kuasaNya itu identik dengan Yesus Kristus yang dilukiskan berjenis kelamin laki-laki dan Bunda Maria yang terlukis berjenis kelamin perempuan.

b. Masyarakat Kampung Tarung mengenal sepasang suami istri bernama Kodalaiya Bili dan Lotalara Seingu sebagai nenek moyang pertama mereka yang tiba di Sumba. Kisah sepasang manusia pertama ini pun ada dalam Alkitab Kejadian 2: 725 dan 1 Timotius 2: 13 "Karena Adam yang pertama dijadikan, kemudian barulah Hawa". Sedangkan, kisah kelahiran dan kematian Yesus, lebih tertuju pada mitos kelahiran manusia pertama versi Marapu Kampung Tarung yaitu Ana Kanissa Kedu - Ana Kanissa Wawi, bila diterjemahkan dalam bahasa Indonesia artinya Anak Tunggal Kera - Anak Tunggal Babi. Berdasarkan penuturan Lidda Mawo Mude (tokoh masyarakat Kampung Tarung), Wulla Poddu berkaitan dengan kisah kematian (pengorbanan) Yesus Kristus sebagai juruselamat.

c. Penghuni rumah-rumah tradisional di Kampung Tarung, selama Wulla Poddu memiliki tugasnya masingmasing. Umma Dara (rumah kuda) berperan menyampaikan pesan hasil keputusan musyarawah Wulla Poddu dari Umma Rato (rumah laki-laki) ke Umma Mawinne (rumah perempuan). Umma Dara inilah rumah atau kandang kuda kepang yaitu kuda pemali yang dipercaya sebagai kuda yang tunggangi oleh nenek moyang orang Kampung Tarung (Kodalaiya Bili dan Lotalara Seingu) selama perjalanan menuju Sumba. Selain itu, menurut penuturan pemuda Kampung Tarung bernama Lado Regi Tera, kandang kuda pemali tersebut adalah tempat lahirnya Pencipta, seperti kisah kelahiran Yesus di kandang domba.

d. Suatu syair sakral yang diucapkan Rato Rumata Kampung Tarung, 
terutama pada saat malam penutupan Wulla Poddu (Kalango) dalam keadaan Trance, yakni tentang perjalanan nenek moyang pertama orang Sumba mengelilingi dunia, dimana dalam syair itu disebutkan bahwa Kodalaiya Bili dan Lotalara Seingu sebelum tiba di Sumba (Tanjung Sasar) melewati tempattempat suci agama mondial juga, seperti Yerusalem, Vatikan, Arab Saudi (Mekkah), India (Sungai Gangga), Tiongkok (Tembok China), dan tempat suci lainnya.

e. Orang Sumba memiliki ciri yang mudah dilihat dari aksesoris yang dikenakan, seperti mamoli (anting), maraga (kalung), dan gadingo (gelang). Benda-benda itu merupakan salah satu bentuk produk budaya Sumba yang hingga kini dikenakan masyarakat setempat. Seiring pengaruh inkulturasi Kristen, anakanak Kampung Tarung terutama kalangan remaja telah banyak mengenakan kalung Salib. Hal ini, diperoleh mereka dari pengaruh lingkungan luar, terlebih di lingkungan sekolah.

Inkulturasi teologis sebagaimana penerapannya, memandang Injil sebagai "tambahan" yang disesuaikan terhadap dasar ajaran Marapu, agar ke-Marapu-an tetap seimbang dan berkesinambungan istilah-istilah Marapu tetap dipergunakan tanpa mengesampingkan istilah Injil (Yesus, Bunda Maria, Adam, Hawa, dll.). Hal tersebut menimbulkan kekaburan terhadap ke-Marapu-an itu sendiri, dimana secara perlahan keMarapu-an mengarah dan tergantikan oleh ke-Kristen-an. Karena masyarakat maupun penganut Marapu Kampung Tarung kerap menggunakan istilah Kristen/Katolik untuk mempermudah pemahaman ke-Marapu-an kepada orang luar terutama terhadap kalangan mereka sendiri, terlebih penyesuaian itu digunakan sebagai pernyataan bahwa Marapu sederajat dengan agama-agama yang diakui secara yuridis oleh pemerintah negara Indonesia.

\section{Simpulan}

Berdasarkan uraian di atas, maka dapat disimpulkan sebagai berikut:

a. Berbagai kebijakan pemerintah negara Indonesia, menciptakan klasifikasi antara penganut agama dan penganut aliran kepercayaan, khususnya Marapu. Diskriminasi persuasif terhadap penganut Marapu berlanjut melalui praktik pendidikan formal semenjak zendeling dan misionaris menggunakan lembaga pendidikan formal sebagai alat pekabaran Injil dan juga berbagai kebijakan yang mengharuskan peserta didik mencantumkan identitas agama agar dapat mengikuti mata pelajaran pendidikan agama (Kristen/Katolik).

b. Marapu yang diposisikan bukan agama dan ajarannya tanpa kitab suci tertulis memudahkan berbagai kalangan menafsirkannya dari hanya menguraikan kata "Marapu", sehingga pemahaman masyarakat Kampung Tarung semakin terpuruk. Dualisme beragama merupakan realitas yang terjadi pada masyarakat Kampung Tarung. Pendidikan formal menjadi alat doktrinisasi yang dimiliki penguasa, berhasil melakukan rekayasa penyesuaian terhadap dasar ajaran Marapu dengan dasar ajaran Kristen/Katolik. Penyesuaian itu dianggap oleh masyarakat Kampung Tarung bahwa Marapu setara dengan keenam agama, tetapi penyesuaian itu melahirkan ke-Marapu-an yang mengarah pada ke-Kristen-an.

\section{Saran}

Berkaitan dengan hal itu, maka penulis memberi saran sebagai berikut: 
Demi keadilan berbangsa dan bernegara, keduanya disederajatkan dalam satu sebutan dan perspektif, yaitu "Agama". Sekolah yang bertujuan mencerdaskan kehidupan bangsa, hendaknya lebih mengedepankan multikulturalisme. Kepada masyarakat Kampung Tarung agar mempertahankan ke-Marapu-an dan tidak keliru dalam menentukan keputusan memperjuangkan hak-hak berke-Tuhan-an.

\section{Daftar Pustaka}

\section{Buku}

Kapita, Oemboe Hina. 2008. Sejarah Pergumulan Injil di Sumba. Waingapu: Sinode Gereja Kristen Sumba.

Subagya, R. 1981. Agama Asli Indonesia. Jakarta: Sinar Harapan dan Yayasan Cipta Loka Caraka.

Tilaar, H.A.R. 2009. Kekuasaan dan Pendidikan: Manajemen Pendidikan Nasional dalam Pusaran Kekuasaan. Jakarta: Rineka Cipta.

\section{Peraturan/Kebijakan Negara}

Penetapan Presiden Republik Indonesia Nomor 1/PNPS/1965 Tentang Pencegahan Penyalahgunaan dan/atau Penodaan Agama.

\begin{tabular}{|c|c|}
\hline Putusan MK RI & Nomor \\
\hline XIV/2016 & Demi \\
\hline $\begin{array}{l}\text { Berdasarkan } \\
\text { Maha Esa. }\end{array}$ & Ketuhanan \\
\hline
\end{tabular}

Undang-Undang Republik Indonesia Nomor 5 Tahun 1969 Tentang Pernyataan Berbagai Penetapan Presiden dan Peraturan Presiden Sebagai Undang-Undang.

Undang-Undang Republik Indonesia Nomor 20 Tahun 2003 Tentang
Sistem Pendidikan Nasional, Pasal 1, 12, dan 37.

\section{Alkitab}

Anonim. 2012. ALKITAB Terjemahan Baru. Jakarta: Lembaga Alkitab Indonesia. (Matius 28: 19-20; Kejadian 1: 1; Kejadian 2: 7-25; dan 1 Timotius 2: 13). 